Jurnal Ilmiah Ibnu Sina, 6(2), Oktober 2021, 292-301

p-ISSN: 2502-647X; e-ISSN: 2503-1902

\title{
HUBUNGAN PENGETAHUAN TERHADAP PERILAKU \\ PENGGUNAAN SUPLEMEN DAN OBAT HERBAL DALAM \\ MENCEGAH PENULARAN COVID-19 DI BANJARBARU SELATAN
}

\author{
Esty Restiana Rusida*, Syahrizal Ramadhani, dan Depy Oktapian Akbar \\ Sekolah Tinggi Ilmu Kesehatan Borneo Lestari \\ *Email: rusidahayesty@gmail.com
}

Artikel diterima: 12 Agustus 2020; Disetujui: 09 September 2021

DOI: https://doi.org/10.36387/jiis.v6i2.728

\begin{abstract}
ABSTRAK
Indonesia termasuk negara terkonfirmasi tertinggi di ASEAN dan Kalimantan Selatan masih dalam kategori urutan ke 13 dalam kasus Covid-19. Tindakan mencegah penyebarannya salah satunya dengan meningkatkan sistem imun yaitu mengkonsumsi suplemen kesehatan ataupun obat herbal. Pengetahuan berpengaruh dalam membentuk perilaku seseorang. Tujuan penelitian ini untuk mengetahui hubungan pengetahuan terhadap perilaku penggunaan suplemen dan obat herbal dalam mencegah penyebaran Covid-19 di Banjarbaru Selatan. Penelitian ini bersifat deskriptif analitik dengan desain cross sectional, pengambilan data dengan teknik proportional random sampling dengan instrumen berupa google form dengan sampel 398 responden. Analisis data yang digunakan yaitu univariat dan bivariat dengan menggunakan chi square. Kesimpulan menunjukkan bahwa tingkat pengetahuan masyarakat tentang suplemen dan obat herbal di kecamatan Banjarbaru Selatan mayoritas berpengetahuan cukup sebesar 43,5 \% dengan perilaku penggunaan suplemen dan obat herbal mayoritas kurang tepat sebesar 68,3\%. Hasil uji statistik chi square menunjukkan ada hubungan pengetahuan terhadap perilaku penggunaan suplemen dan obat herbal dengan nilai 0,000 (sig. $<0,05$ ).
\end{abstract}

Kata kunci: Pengetahuan, Perilaku, Suplemen, Obat Herbal

\section{ABSTRACT}

Indonesia is one of the highest confirmed countries in ASEAN and South Kalimantan is still in the 13th order category in Covid-19 cases. One of the measures to prevent its spread is to increase the immune system by consuming health supplements or herbal medicines. Knowledge influences in shaping one's behavior. The purpose of this study was to determine the relationship between knowledge and behavior in the use of supplements and herbal medicines in preventing the spread of Covid-19 in South Banjarbaru. This research is descriptive analytic with a cross sectional design, data collection by proportional random sampling technique with an instrument in the form of google form with a sample of 398 respondents. The data analysis used is univariate and bivariate using chi square. The conclusion shows that the level of public knowledge about 
Jurnal Ilmiah Ibnu Sina, 6(2), Oktober 2021, 292-301

p-ISSN: 2502-647X; e-ISSN: 2503-1902

supplements and herbal medicines in the South Banjarbaru sub-district is mostly knowledgeable enough by $43.5 \%$ with the majority of the behavior of using supplements and herbal medicines being inappropriate at $68.3 \%$. The results of the chi square statistical test showed that there was a relationship between knowledge and behavior in the use of supplements and herbal medicines with a value of 0.000 (sig. <0.05).

Keywords: Knowledge, Behavior, Supplements, Herbal Medicine

\section{PENDAHULUAN}

Indonesia termasuk negara terkonfirmasi tertinggi di ASEAN dan Kalimantan Selatan masih dalam kategori urutan ke 13 dalam kasus Covid-19 yang terkonfirmasi. Data yang diperoleh untuk provinsi Kalimantan Selatan sebanyak 14.075 jumlah kasus positif $(2.3 \%$ dari jumlah terkonfirmasi nasional), 12.627 jumlah kasus sembuh $(89.7 \%$ dari jumlah terkonfirmasi provinsi), 553 jumlah kasus meninggal (3.9\% dari jumlah terkonfirmasi provinsi). Data yang masuk tentang perkembangan sebaran Covid-19 di kota Banjarbaru pada tanggal 12 Desember 2020 pukul 16.00 WITA di kecamatan Banjarbaru Selatan adalah orang dalam pemantauan (ODP) sebanyak lima orang, pasien dalam pengawasan (PDP) tidak ada, dan positif enam orang. Jadi data yang terkumpul 12 Desember pada pukul 16.00 WITA, yang terkonfirmasi positif hari ini di kota Banjarbaru ada sebanyak 1445 orang, yang masih dirawat sebanyak 23 orang, orang sembuh sebanyak 1237, dan total yang meninggal sebanyak 63 orang (Diskominfo, 2020).

Rekomendasi WHO yang dapat mencegah penyebarannya dengan cara menggunakan masker, menjaga jarak, meningkatkan sistem imun yaitu mengkomsumsi suplemen kesehatan ataupun obat herbal. Awal masa pandemi Covid-19 masyarakat berbondong-bondong membeli suplemen kesehatan, sehingga mengalami kekosongan. Namun sebagian masyarakat juga memilih obat herbal karena sama-sama meningkatkan daya tahan tubuh. Suplemen kesehatan adalah produk untuk melengkapi kebutuhan zat gizi, memelihara, meningkatkan atau memperbaiki, mengandung satu atau lebih bahan berupa vitamin, mineral, asam amino dan/atau bahan lain 
Jurnal Ilmiah Ibnu Sina, 6(2), Oktober 2021, 292-301

p-ISSN: 2502-647X; e-ISSN: 2503-1902

bukan tumbuhan yang dapat perilaku penggunaan suplemen dan dikombinasi dengan tumbuhan obat herbal dalam mencegah (BPOM, 2019). penularan Covid-19 di wilayah Penelitian sebelumnya yang Banjarbaru Selatan.

dilakukan oleh Mukti (2020) melihat hubungan pengetahuan terhadap perilaku penggunaan suplemen kesehatan warga Kebonsari Surabaya di masa pandemi Covid-19 pada tahun 2020 menunjukkan sebagian besar responden tergolong baik (40\%) dan cukup (41\%), hasil dari nilai total perilaku penggunaan suplemen kesehatan dapat tergolong tepat (95,3\%), sehingga dapat disimpulkan bahwa ada pengaruh pengetahuan terhadap perilaku.

Tingkat pengetahuan oleh seseorang akan suatu pengobatan akan berdampak kepada tingkat kepercayaannya dan perilakunya terhadap pengobatan tersebut (Khairunnisa, 2017). Pengetahuan mempunyai pengaruh besar dalam menentukan keberhasilan suatu penanggulangan penyakit dalam mencegah Covid-19 (Romziyah, 2020).

Tujuan penelitian ini adalah untuk mengetahui dan melihat hubungan pengetahuan terhadap

\section{METODE PENELITIAN}

Penelitian ini merupakan penelitian deskriptif analitik non eksperimental dengan menggunakan pendekatan cross sectional yang pengambilan data variabel independen dan variabel dependen dilakukan pada satu saat atau satu periode tertentu dan pengamatan terhadap 398 subjek di wilayah Banjarbaru Selatan yang memenuhi kriteria; responden yang berdomisili di Banjarbaru Selatan; bersedia menjadi reponden, mampu mengisi googleform yang diberikan; mengkonsumsi suplemen dan/atau obat herbal minimal 12 bulan terakhir. Kriteria eksklusi pada penelitian ini adalah tenaga kesehatan, responden yang tidak lengkap mengisi kuesioner.

Instrumen yang digunakan dalam penelitian ini berupa kuesioner berbasis daring melalui google form. Kuesioner yang digunakan yaitu kuesioner pengetahuan tentang 
Jurnal Ilmiah Ibnu Sina, 6(2), Oktober 2021, 292-301

p-ISSN: 2502-647X; e-ISSN: 2503-1902

suplemen yang terdiri dari 10 pertanyaan dengan kategori berdasarkan skor baik 76\%-100\%, cukup 56\%-76\%, dan kurang $<56 \%$. Kuesioner yang digunakan telah dilakukan uji validitas dan uji reliabilitas di Kecamatan Banjarbaru Utara tahun 2021 dengan jumlah sampel 30 responden dan menunjukkan kuesioner yang digunakan valid dan reliabel dengan cronbach`s alpha 0,836

Kuesioner yang digunakan untuk mengukur perilaku penggunaan suplemen dan obat herbal terdiri dari 24 pertanyaan dengan kategori perilaku tepat skor 72-96, perilaku kurang tepat skor 48-71, dan tidak tepat dengan skor 24-47. Kuesioner telah dilakukan uji validasi dan uji reliabilitas dan menunjukkan kuesioner valid dan reliabel dengan cronbach's alpha 0,930. Pengambilan data dilakukan dengan cara pembagian link kuisoner yang telah valid dan realiabel (Notoatmodjo, 2012).

Analisis data yang digunakan adalah analisis univariat dan bivariat. Dengan kategori sebagai berikut :
Tabel 1. Kategori Tingkat Pengetahuan

\begin{tabular}{|c|c|}
\hline $76 \%-100 \%$ & Baik \\
\hline $56 \%-76 \%$ & Cukup \\
\hline$<56 \%$ & Kurang \\
\hline \multicolumn{2}{|c|}{ Sumber: Budiman, 2013} \\
\hline \multicolumn{2}{|c|}{ Tabel 2. Kategori Penilaian Perilaku } \\
\hline Nilai Skor & Kategori \\
\hline $72-96$ & Perilaku tepat \\
\hline $48-71$ & Perilaku kurang tepat \\
\hline $24-47$ & Perilaku tidak tepat \\
\hline
\end{tabular}

Analisis bivariate digunakan untuk melihat hubungan antara tingkat pengetahuan dan perilaku penggunaan suplemen dan obat herbal dalam pencegahan covid 19 .

Interpretasi data dilihat dari nilai signifikansi yang diperoleh, jika nilai sig< 0,05 maka $\mathrm{HO}$ ditolak sehingga dapat ditarik kesimpulan bahwa ada pengaruh antara variabel bebas terhadap variabel terikat (Mann, 2013).

\section{HASIL DAN PEMBAHASAN}

Berdasarkan tabel 3 karakteristik responden menunjukkan bahwa berdasarkan jenis kelamin yaitu pada jenis kelamin perempuan lebih banyak sebesar 52,26\%. 
Jurnal Ilmiah Ibnu Sina, 6(2), Oktober 2021, 292-301

p-ISSN: 2502-647X; e-ISSN: 2503-1902

Menurut penelitian Kurniawati (2019)

menyatakan bahwa perempuan cenderung lebih peduli pada masalah kesehatan dibandingkan laki-laki, kepeduliannya pada kesehatan bukan hanya untuk dirinya pribadi akan tetapi untuk anak dan keluarganya. Hasil persentase berdasarkan usia yaitu responden berusia 18-25 tahun lebih banyak sebesar 72,36\%.

\section{a. Karakteristik Responden}

Tabel 3. Karakteristik Responden

\begin{tabular}{|c|c|c|}
\hline $\begin{array}{c}\text { Karakteristik } \\
\text { Responden }\end{array}$ & Jumlah & $\begin{array}{c}\text { Persentase } \\
(\%)\end{array}$ \\
\hline \multicolumn{3}{|l|}{ Jenis Kelamin } \\
\hline Perempuan & 208 & 52,26 \\
\hline Laki-laki & 190 & 47,74 \\
\hline Jumlah & 398 & 100 \\
\hline \multicolumn{3}{|l|}{ Usia (Tahun) } \\
\hline $18-25$ & 288 & 72,36 \\
\hline $26-35$ & 64 & 16,08 \\
\hline $36-45$ & 20 & 5,03 \\
\hline $46-55$ & 19 & 4,77 \\
\hline $56-65$ & 7 & 1,76 \\
\hline Jumlah & 398 & 100 \\
\hline \multicolumn{3}{|l|}{ Pendidikan Terakhir } \\
\hline SD/sederajat & 10 & 2,51 \\
\hline SMP/sederajat & 40 & 10,05 \\
\hline SMA/sederajat & 260 & 65,33 \\
\hline $\begin{array}{l}\text { Diploma/Sarjana/ } \\
\text { Panca Sarjana }\end{array}$ & 88 & 22,11 \\
\hline Jumlah & 398 & 100 \\
\hline \multicolumn{3}{|l|}{ Perkerjaan } \\
\hline Tidak Bekerja & 239 & 60,05 \\
\hline Bekerja & 159 & 39,95 \\
\hline Jumlah & 398 & 100 \\
\hline \multicolumn{3}{|c|}{ Terakhir Mengkonsumsi (Bulan) } \\
\hline $10-12$ & 74 & 18,59 \\
\hline $6-9$ & 110 & 27,64 \\
\hline $3-5$ & 101 & 25,38 \\
\hline $1-2$ & 113 & 28,39 \\
\hline Jumlah & 398 & 100 \\
\hline
\end{tabular}

Menurut Romziyah (2020) menyatakan usia kelompok 17-25 tahun ini terkait dengan kelompok usia yang paling aktif menggunakan jejaring sosial Whatsapp dalam kehidupan sehari-hari dan persentase orang yang bersedia mengisi kuesioner ini paling tinggi. Hasil persentase berdasarkan pendidikan terakhir yaitu responden terbanyak dengan pendidikan SMA/sederajat sebesar 65,33\%. Menurut Carter (2011) bahwa semakin tinggi tingkat pendidikan seseorang maka akan semakin mudah menerima informasi sehingga semakin banyak pula pengalaman yang dimiliki dalam hal ini khususnya tentang kesehatan. Hasil persentase berdasarkan pekerjaan yaitu responden yang tidak bekerja lebih banyak sebesar 60,05\%. Tidak bekerja dibagi menjadi ibu rumah tangga, pelajar atau mahasiswa, dan pensiun. Ini dapat dikaitkan dengan persentase karakteristik berdasarkan usia. Hasil persentase berdasarkan terakhir menggunakan suplemen dan /atau obat herbal yaitu responden yang terakhir mengkonsumsi 1-2 bulan terakhir merupakan responden yang 
Jurnal Ilmiah Ibnu Sina, 6(2), Oktober 2021, 292-301

p-ISSN: 2502-647X; e-ISSN: 2503-1902

terbanyak sebesar 28,39. Periode ini menandakan bahwa responden rutin melakukan pencegahan selama pandemi ini.

b. Analisis

Pengetahuan

Suplemen Dan Obat Herbal

Dalam Mencegah Penularan Covid-19

Tabel 4. Kategori Pengetahuan Suplemen Dan Obat Herbal Dalam Mencegah Penularan Covid-19

\begin{tabular}{ccc}
\hline Kategori & Jumlah & $\begin{array}{c}\text { Persentase } \\
(\%)\end{array}$ \\
\hline Kurang & 65 & 16,3 \\
Cukup & 173 & 43,5 \\
Baik & 160 & 40,2 \\
\hline Total & 398 & 100 \\
\hline
\end{tabular}

Berdasarkan Tabel 4 diatas dapat disimpulkan bahwa responden memiliki pengetahuan suplemen dan obat herbal dalam kategori cukup sebesar 43,5\%. Menurut Fitriani (2015) beberapa hal yang dapat mempengaruhi pengetahuan seseorang seperti pendidikan, media massa/informasi, sosial budaya, ekonomi, lingkungan, pengalaman dan usia. Pengetahuan adalah salah satu hal yang penting diperhatikan dalam rangka pencegahan kasus Covid-19 (Yanti, 2020). Penelitian Zhong (2020) menemukan hubungan signifikan karakteristik sosiodemografi berupa jenis kelamin, kelompok usia, status pernikahan, tingkat pendidikan, dan asal daerah masyarakat China terhadap pengetahuan tentang COVID-19 $(\mathrm{p}<0,001)$. Pengetahuan yang banyak akan memberikan dampak yang baik dan menghasilkan respon atau perilaku yang baik pula. Dalam penelitian oleh Zhong (2020) disebutkan bahwa $82,4 \%$ sampel penelitian berpendidikan diploma atau lebih tinggi. Pada penelitian tersebut ditemukan hubungan antara tingkat pendidikan dengan skor pengetahuan, sehingga disebutkan bahwa situasi epidemik dan berita yang banyak mengenai keadaan darurat kesehatan yaitu COVID-19 membuat populasi secara aktif mempelajari pengetahuan mengenai penyakit ini dari beberapa saluran informasi dan situs resmi pemerintah (Zhong, 2020). 
Jurnal Ilmiah Ibnu Sina, 6(2), Oktober 2021, 292-301

p-ISSN: 2502-647X; e-ISSN: 2503-1902

c. Analisis Perilaku Penggunaan Suplemen Dan Obat Herbal Dalam Mencegah Penularan Covid-19

Tabel 5. Kategori Perilaku Penggunaan suplemen dan obat herbal

\begin{tabular}{ccc}
\hline Kategori & Jumlah & $\begin{array}{c}\text { Persentase } \\
(\%)\end{array}$ \\
\hline Perilaku Tepat & 125 & 31,4 \\
Perilaku Kurang & 273 & 68,6 \\
Tepat & & 0 \\
\hline Perilaku Tidak Tepat & 0 & 100 \\
\hline Total & 398 & \\
\hline
\end{tabular}

Berdasarkan Tabel 5 diatas dapat disimpulkan bahwa perilaku menunjukkan kategori berperilaku kurang tepat sebesar $68,3 \%$. Perilaku merupakan seperangkat perbuatan atau tindakan seseorang dalam melakukan respon terhadap sesuatu dan kemudian dijadikan kebiasaan karena adanya nilai yang diyakini. Berdasarkan penelitian Khadka (2021) bahwa penggunaan tanaman obat meningkat selama COVID-19 dan sebagian besar responden merekomendasikan tanaman obat untuk mencegah COVID-19. Penelitian ini mencatat total 60 tanaman yang miliki 36 famili. Daun tanaman yang paling sering digunakan Zingiber officinale. d. Analisis

Pengetahuan

Perilaku

Suplemen Dan Obat Herbal

Dalam Mencegah Penularan

\section{Covid-19}

Tabel 6 . Analisis Hubungan

Pengetahuan Terhadap Perilaku Penggunaan

Suplemen Dan Obat Herbal

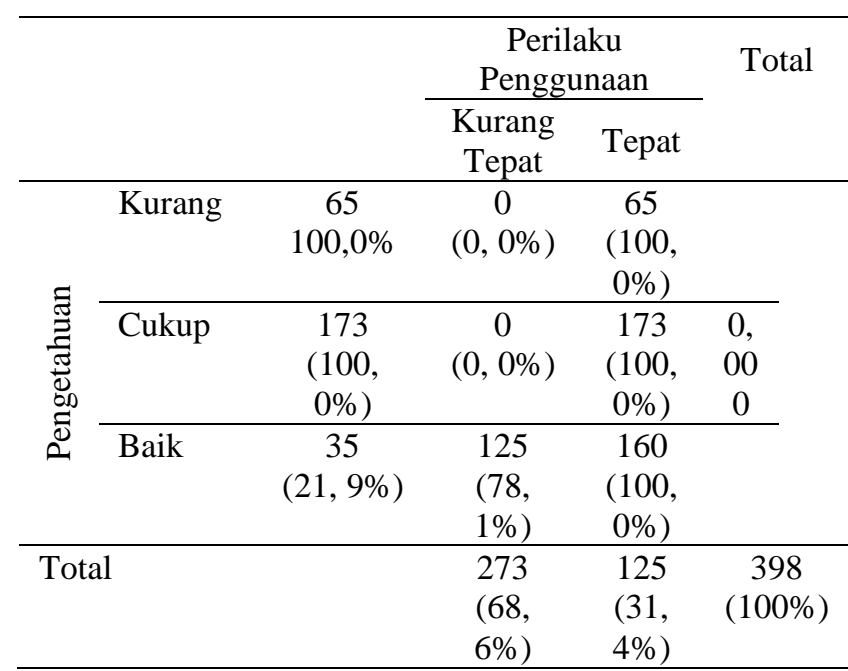

Berdasarkan Tabel 6 diatas hasi uji analisis Chi square adalah sebesar 0,000 yaitu (sig. < 0, 05) dapat disimpulkan ada hubungan pengetahuan terhadap perilaku penggunaan suplemen dan obat herbal dalam mencegah penularan Covid-19 di Banjarbaru Selatan. Menurut Notoatmodjo (2014), pengetahuan dipengaruhi oleh pengalaman seseorang dan lingkungan yang kemudian dapat diekspresikan dan 
Jurnal Ilmiah Ibnu Sina, 6(2), Oktober 2021, 292-301

p-ISSN: 2502-647X; e-ISSN: 2503-1902

diyakini sehingga menimbulkan motivasi. Pekerjaan dan latar belakang pendidikan/pekerjaan yang ditemukan berhubungan dengan tingkat pengetahuan terhadap COVID-19 pada penelitian ini dapat diasumsikan sejalan dengan teori Bloom revisi dan Notoatmodjo.

Perilaku kesehatan masyarakat dapat dipengaruhi antara lain oleh faktor pengetahuan, keyakinan, nilainilai, sikap, fasilitas dan sarana kesehatan, sumber daya, dan tokoh masyarakat, pelayanan petugas kesehatan, teman, serta keluarga (Notoadmodjo, 2010). Pengetahuan sangat berpengaruh dalam membentuk perilaku seseorang (Notoatmodjo, 2012). Perilaku akan bertahan lama bila didasarkan oleh pengetahuan, sedangkan perilaku tidak akan bertahan lama bila tidak didasarkan oleh pengetahuan.

Meningkatkan pengetahuan dapat dilakukan dengan berbagai media atau membagikan informasi di poster yang berisi himbauan dan edukasi terkait pencegahan Covid-19. Pembagian poster ini dapat dilakukan secara langsung atau ditempel pada tempat yang mudah dibaca dan lokasi yang strategis. Informasi, edukasi dan pengawasan harus tetap dilakukan agar masyarakat mau menerapkan perilaku yang sehat. Berdasarkan penelitian

\section{KESIMPULAN}

Berdasarkan penelitian yang telah dilakukan dapat disimpulkan sebagai berikut:

(1) Tingkat pengetahuan masyarakat tentang suplemen dan obat herbal dalam mencegah penularan Covid-19 di Banjarbaru Selatan berpengetahuan cukup sebesar $43,5 \%$.

(2) Perilaku masyarakat tentang penggunaan suplemen dan obat herbal dalam mencegah penularan Covid-19 di Banjarbaru Selatan memiliki perilaku kurang tepat sebesar $68,6 \%$.

(3) Ada hubungan pengetahuan terhadap perilaku penggunaan suplemen dan obat herbal dalam mencegah penularan Covid-19 di Banjarbaru Selatan dengan nilai 0,000 (sig. < 0, 05). 
Jurnal Ilmiah Ibnu Sina, 6(2), Oktober 2021, 292-301

p-ISSN: 2502-647X; e-ISSN: 2503-1902

\section{DAFTAR PUSTAKA}

BPOM, 2019, Peraturan Kepala Badan Pom No.16 Tahun 2019 Tentang Pengawasan Suplemen Kesehatan, BPOM RI, Jakarta.

Budiman \& Riyanto A. 2013. Kapita Selekta Kuisioner Pengetahuan Dan Sikap Dalam Penelitian Kesehatan. Salemba Medika, Jakarta

Carter, 2011, Disaster Management : A Disaster manager's Handbook, Manila: ADB.

Diskominfo, 2020, Data Sebaran COVID-19 Kota Banjarbaru Selasa, 12 Desember 2020, Diakses pada 13 Desember 2020, dari https://diskominfo.banjarbaruko ta.go.id/data-sebaran-covid-19kota banjarbaru-sabtu-12desember-2020/

Fitriani NL \& Andriyani S, 2015, Hubungan Antara Pengetahuan Dengan Sikap Anak Usia Sekolah Akhir (10-12 Tahun) Tentang Makanan Jajanan Di Sd Negeri Ii Tagog Apu Padalarang Kabupaten Bandung Barat Tahun 2015, Jurnal Pendidikan Keperawatan Indonesia, Vol 1(01), Hal 7-26.

Khairunnisa, N.A., \& Tanuwijaya, J. 2017, Tingkat Pengetahuan Pasien Dan Rasionalitas Swamedikasi Di Tiga Apotek Kota Panyabungan. J. Sains Farm. Vol 3(2), Hal 186-192.

Mann, P.S. 2013. Introductory Statistics $8^{\text {th }}$ Edition. United States of America.

Mukti, A. W, 2020, Hubungan Pengetahuan terhadap Perilaku
Penggunaan Suplemen

Kesehatan Warga Kebonsari Surabaya di Masa Pandemi Covid-19, Jurnal Sains Farmasi, Vol 1(01), Hal 20-25.

Notoatmodjo, S, 2010, Promosi Kesehatan dan Perilaku Kesehatan, Jakarta: Rineka Cipta.

Notoatmodjo, S, 2012, Metodologi Penelitian Kesehatan. Jakarta: Rineka Cipta.

Notoatmodjo S. 2014. Ilmu Perilaku Kesehatan. 2nd ed. Jakarta: Rineka Cipta

Romziyah, dkk, 2020, Hubungan Tingkat Pengetahuan Dan Sikap Masyarakat Dalam Upaya Pencegahan Covid-19 Menggunakan

Immunomodulator Herbal Di Desa Kenteng Kecamatan Susukan Kabupaten Semarang. Skripsi, Universitas Ngudi Waluyo.

Yanti, dkk, 2020, Gambaran pengetahuan masyarakat tentang covid-19 dan perilaku masyarakat di masa pandemi covid-19. Jurnal Keperawatan Jiwa. Vo, 8 (03). Hal 485-490.

Zhong, B.L., Luo, W., Li H.M., Zhang, Q.Q., Liu, X.G., Li, W.T,... 2020. Knowledge, attitudes, and practices towards COVID-19 among Chinese residents during the rapid rise period of the COVID-19 outbreak: a quick online crosssectional survey. Int $J$ Biol Sci,16(10):1745-52. 